\title{
Benthic Suffocation of Invasive Lake Trout Embryos by Fish Carcasses and Sedimentation in Yellowstone Lake
}

\section{Authors: Alex S. Poole, Todd M. Koel, Nathan A. Thomas, \& Alexander V. Zale}

This is the peer reviewed version of the following article: [Benthic Suffocation of Invasive Lake Trout Embryos by Fish Carcasses and Sedimentation in Yellowstone Lake. North American Journal of Fisheries Management 40, 5 p1077-1086, which has been published in final form at https://doi.org/10.1002/nafm.10492. This article may be used for non-commercial purposes in accordance with Wiley Terms and Conditions for Use of Self-Archived Versions: https:// authorservices.wiley.com/author-resources/Journal-Authors/licensing/self-archiving.html\#3.

Poole, Alex S., Todd M. Koel, Nathan A. Thomas, and Alexander V. Zale. "Benthic Suffocation of Invasive Lake Trout Embryos by Fish Carcasses and Sedimentation in Yellowstone Lake." North American Journal of Fisheries Management 40, no. 5 (September 9, 2020): 1077-1086.

doi:10.1002/nafm.10492.

Made available through Montana State University's ScholarWorks 
North American Journal of Fisheries Management

ARTICLE

Benthic Suffocation of Invasive Lake Trout Embryos by Fish Carcasses and

Sedimentation in Yellowstone Lake

Alex S. Poole*1

Montana Cooperative Fishery Research Unit, Montana State University, MSU - PO Box 173460, Bozeman, Montana 59717-3460, USA

\section{Todd M. Koel}

U.S. National Park Service, Yellowstone Center for Resources, Native Fish Conservation Program, Post Office Box 168, Yellowstone National Park, Wyoming 82190, USA

\section{Nathan A. Thomas}

U.S. National Park Service, Yellowstone Center for Resources, Native Fish Conservation Program, Post Office Box 168, Yellowstone National Park, Wyoming 82190, USA

\section{Alexander V. Zale}

U.S. Geological Survey, Montana Cooperative Fishery Research Unit, Department of Ecology, Montana State University, MSU - PO Box 173460, Bozeman, Montana 597173460, USA

*Corresponding author: alex.poole@mt.gov

${ }^{1}$ Present address: Montana Fish, Wildlife \& Parks, 4600 Giant Springs Road, Great Falls, Montana 59405, USA

This draft manuscript is distributed solely for the purposes of scientific peer review. Its content is deliberative and predecisional, so it must not be disclosed or released by reviewers. Because the manuscript has not yet been approved for publication by the U.S. Geological Survey (USGS), it does not represent any official USGS finding or policy. 
Abstract.-Introduced Lake Trout Salvelinus namaycush threaten native Yellowstone Cutthroat Trout Oncorhynchus clarkii bouvieri in Yellowstone Lake, Yellowstone National Park, where gill nets have been used to suppress subadult and adult Lake Trout since 1995. However, survival of embryonic and larval life history stages can have profound effects on population dynamics of Lake Trout. Inducing additional mortality at those stages, especially if used in concert with intensive gillnetting of older fish, could enhance overall suppression efforts. Therefore, we conducted controlled field experiments at Yellowstone Lake to systematically evaluate the effects of sediment deposition and ground Lake Trout carcass deposition on Lake Trout embryos in prepositioned incubators. Sediment deposition caused dissolved oxygen concentrations to decline below lethal levels for a prolonged period (92 d) overwinter. Embryo mortality among overwintering incubators varied from $97 \pm 5.3 \%$ at the substrate surface to $100 \pm$ $0.0 \% 20 \mathrm{~cm}$ below the substrate surface. Decomposition of ground carcass material on spawning sites caused dissolved oxygen concentrations to decline to lethal levels $(<3.4$ $\mathrm{mg} / \mathrm{L}$ ) for about 9 days following biomass application rates of 14 and $28 \mathrm{~kg} / \mathrm{m}^{2}$ in treatment plots. Exposure to ground carcass material resulted in $100 \pm 0.0 \%$ (mean $\pm \mathrm{SE})$ embryo mortality at the substrate surface and within interstices $20 \mathrm{~cm}$ below the surface in 14 and $28 \mathrm{~kg} / \mathrm{m}^{2}$ biomass treatments. Embryo mortality was probably caused by hypoxic conditions within substrates in both experiments. The deposition of sediment and ground Lake Trout carcass material on Lake Trout spawning sites in Yellowstone Lake could provide an additional source of mortality in ongoing Lake Trout suppression efforts. These methods may also be beneficial in other systems when incorporated in an 
Integrated Pest Management approach targeting multiple life history stages of invasive freshwater fish. 


\section{$\underline{\text { Introduction }}$}

Unauthorized nonnative fish introductions can burden agencies and society by subverting management and conservation efforts, threatening native species with extinction, damaging sustainable recreational fisheries, and diverting agency resources into expensive and often perpetual remediation programs (Pimentel et al. 2005; Johnson et al. 2009). Of particular concern are introductions of nonnative predatory fishes that are desired by the angling public (Martinez et al. 2009) but that can exert top-down effects that can alter entire food webs, even in large lakes (McMahon and Bennett 1996). For example, Walleye Sander vitreus, Northern Pike Esox lucius, and Lake Trout Salvelinus namaycush recently illegally introduced in lakes of the Pacific Northwest prey upon and compete with native and sport fishes (McMahon and Bennett 1996; Koel et al. 2005; Cox et al. 2013). The introduction of Lake Trout in Yellowstone Lake, Yellowstone National Park, Wyoming, is the most highly publicized example of this fisheries resource issue (Martinez et al. 2009).

The discovery of Lake Trout in Yellowstone Lake in July 1994 raised immediate concern for the native Yellowstone Cutthroat Trout Oncorhynchus clarkii bouvieri population (Kaeding et al. 1996; Ruzycki et al. 2003). The adfluvial Yellowstone Cutthroat Trout population of Yellowstone Lake is the most abundant unhybridized inland cutthroat trout population in existence (Gresswell 2011) and is important for maintaining the integrity of the Yellowstone Lake ecosystem. Yellowstone Cutthroat Trout are a desirable food source for predators such as grizzly bears Ursus arctos horribilis and osprey Pandion haliaetus and thus serve as an important link between 
aquatic and terrestrial environments (Koel et al. 2019). In addition to their ecological importance, Yellowstone Cutthroat Trout have considerable socioeconomic and historical significance in Yellowstone National Park (Varley and Schullery 1995). Yellowstone Lake and its outlet downstream to the Upper Falls of the Yellowstone River are the most popular fisheries in the park (Varley and Schullery 1995). Nonconsumptive uses of Yellowstone Cutthroat Trout, such as viewing platforms at Fishing Bridge and LeHardy Rapids, were estimated to be used by over a third of a million visitors annually in the early 1990s (Gresswell and Liss 1995).

Yellowstone National Park initiated a gillnetting suppression program in 1995 to minimize the effect of Lake Trout on Yellowstone Cutthroat Trout and the Yellowstone Lake ecosystem (Koel et al. 2020a). Nevertheless, the Cutthroat Trout population of Yellowstone Lake declined precipitously (Syslo et al. 2016). The National Park Service contracted with a private-sector fishing company, Hickey Brothers, LLC (Baileys Harbor, Wisconsin), beginning in 2009 to achieve necessary gillnetting effort on Yellowstone Lake for successful suppression. As of November 2019, > 3.35 million Lake Trout had been removed from Yellowstone Lake by the gillnetting program. Yellowstone Cutthroat Trout have yet to reach primary desired conditions as outlined for Yellowstone National Park in the Native Fish Conservation Plan (Koel et al. 2010) because of an expected lag in the gillnetting response (Koel et al. 2020a). Accordingly, managers are seeking alternative forms of Lake Trout suppression to complement gillnetting and increase efficiency of maintaining a suppressed population during the coming decades. 
Development of new control techniques requires consideration of the life history characteristics of the target species (Simberloff 2014). Demographic studies have demonstrated that Lake Trout population growth rates are most sensitive to age- 0 survival rates (Ferreri et al. 1995; Cox et al. 2013; Ng et al. 2016; Fredenberg et al. 2017), indicating this stage is most likely to influence population dynamics. Moreover, Lake Trout are broadcast spawners that typically deposit embryos over clean porous cobble substrate with deep interstitial spaces (Gunn 1995; Marsden et al. 1995; Callaghan et al. 2016) at depths ranging from $<1$ to $30 \mathrm{~m}$ (Koel et al. 2020b). Such substrate is often spatially limited (Cox 2010; Fredenberg et al. 2017); in Yellowstone Lake, it represents only $0.03 \%$ of the surface water area (Koel et al. 2020b).

Degradation of interstitial water quality of Lake Trout spawning sites has not been investigated extensively as an approach to embryo suppression. Salmonid embryos are passive recipients of prevailing water conditions (Finn 2007) and deteriorated water quality has been implicated in recruitment failure and subsequent extirpation of Lake Trout from lakes within their native range (Gunn and Keller 1984; Haines and Baker 1986). Natural degradation of spawning sites is thought to be influenced by two major processes: smothering and infilling by sediment and the decomposition of organic matter within the substrate (Sly 1988). Therefore, intentional degradation of interstitial water quality at spawning sites through the application of sediment and organic matter may efficiently reduce embryo survival. Hypoxic conditions following decomposition of whole fish carcasses and organic pellets at treated spawning sites in Yellowstone Lake caused high Lake Trout embryo mortality (Thomas et al. 2019; Koel et al. 2020b). 
Accordingly, we conducted controlled in-situ experiments to evaluate the effects of sediment deposition and ground fish-carcass deposition on Lake Trout embryo mortality. Specific objectives were to 1) evaluate the effect of sediment deposition on embryo mortality and dissolved oxygen concentrations at different durations of sediment cover, and 2) evaluate the effect of ground fish-carcass deposition on embryo mortality and dissolved oxygen concentrations at different levels of ground carcass biomass and exposure durations in experimental plots. We exposed sentinel Lake Trout embryos to the various treatment types in retrievable incubators and compared post-treatment mortality among treatments.

[A]Methods

[C]Study area.- Yellowstone Lake is located in northwest Wyoming in the eastcentral portion of Yellowstone National Park (Figure 1). Yellowstone Lake lies at an elevation of 2,356 $\mathrm{m}$ near the headwaters of the Yellowstone River and is isolated by large waterfalls $25 \mathrm{~km}$ downstream of its outlet. Yellowstone Lake has a surface area of 36,017 ha, a mean depth of $48 \mathrm{~m}$, and a maximum depth of $107 \mathrm{~m}$ (Kaplinski 1991). Ice cover typically occurs from late December through May, and the lake becomes thermally stratified during July to September with a thermocline developing at a depth of 12-15 m (Koel et al. 2019; Koel et al. 2020a). Hypolimnetic waters below the thermocline remain well oxygenated throughout the summer and surface water temperature rarely exceeds $18^{\circ} \mathrm{C}$ (Benson 1961). Two native fishes and four established nonnatives inhabit Yellowstone Lake. Yellowstone Cutthroat Trout and Longnose Dace Rhinichthys cataractae are native (Varley and Schullery 1998). Longnose Sucker Catostomus 
catostomus, Lake Chub Couesius plumbeus, Redside Shiner Richardsonius balteatus, and Lake Trout were introduced.

[C]Experimental design, site preparation, and data collection. - Embryo mortality experiments were conducted at two confirmed Lake Trout spawning sites (Figure 1). Scuba divers delineated $3 \times 3 \mathrm{~m}$ experimental plots using polypropylene rope weighted at each corner within suitable spawning substrate (5 to $50 \mathrm{~cm}$ angular cobble; Wagner 1982) at each site in depths varying from 1.5 to $3.0 \mathrm{~m}$ below the water surface. Twelve plastic grid incubators were placed in each $3 \times 3 \mathrm{~m}$ plot at two depth strata, including the substrate surface $(0 \mathrm{~cm})$ and at $20 \mathrm{~cm}$ below the substrate surface (Thomas et al. 2019). MiniDot loggers (Precision Measurement Engineering, sampling interval 60 min) were placed within plots at the substrate surface to monitor dissolved oxygen concentrations and temperatures.

Embryos were obtained by manually spawning sexually mature Lake Trout from Yellowstone Lake and were incubated at $9^{\circ} \mathrm{C}$ in Living Stream (Frigid Units, Toledo, Ohio) recirculating tanks until initiation of experiments. Plastic grid incubators were loaded with 50 fertilized embryos $24 \mathrm{~h}$ before placement in experimental plots. Incubators were secured using stainless steel bolts and locking washers to preclude escapement of embryos or fry. Incubators were transferred by boat to experimental plots where divers placed incubators on (i.e., $0 \mathrm{~cm}$ ) or within (i.e., $20 \mathrm{~cm}$ ) the substrate. The number of live embryos in each incubator was recorded prior to deployment.

[C]Sediment deposition. - Sediment deposition treatments were conducted at Carrington Island in the West Thumb of Yellowstone Lake (Figure 1). Spawning 
substrate surrounding Carrington Island was experimentally divided into two halves, with the north half considered the treatment area and the south half considered the control. Three $3 \times 3 \mathrm{~m}$ experimental plots were established in each half. This nonrandom assignment was designed to minimize transfer of sediment from treatment to control plots by prevailing winds and fetch. Nearby fine sediment was collected using a Piranha MiniDredge Model PS165E suction dredge (Piranha Pumps, Albuquerque, New Mexico) and deposited onto the treatment area of the Carrington Island spawning substrates to an average height of $36 \mathrm{~cm}$ above the substrate surface.

[C]Ground carcass deposition. - Ground carcass deposition treatments were conducted at Thomas Bank in Flat Mountain Arm (Figure 1). Lake Trout carcasses were collected from ongoing National Park Service Lake Trout suppression efforts and processed using a CHP-H22 Piranha Bait Chopper (Yaquina Boat Equipment, Toledo, Ohio). Twelve $3 \times 3 \mathrm{~m}$ plots were distributed within a sampling frame extending along $120 \mathrm{~m}$ of shoreline and were divided into four groups of three. Three plots served as control plots, three received $7 \mathrm{~kg} / \mathrm{m}^{2}$ of ground carcasses (light treatment), three received $14 \mathrm{~kg} / \mathrm{m}^{2}$ of ground carcasses (medium treatment), and three received $28 \mathrm{~kg} / \mathrm{m}^{2}$ of ground carcasses (heavy treatment) (Figure 2). Treatments were segregated spatially to reduce effects of potential carcass drift among plots (Thomas et al. 2019). Lake Trout carcass material was deposited by dumping plastic bins with pre-weighed ground carcass material directly onto treatment plots from the research vessel.

[C]Data analyses.- Two experiments were performed at each site: a short-term exposure (18 days at Carrington Island, 19 days at Thomas Bank) and a long-term 
exposure (249 days at Carrington Island, 256 days at Thomas Bank). Incubators were collected at the conclusion of each experiment and the numbers of live embryos (shortterm), or live fry (long-term) were recorded. Percent mortality of each incubator was calculated by dividing the number of live embryos or fry post-treatment by the number of live embryos pre-treatment, subtracting the proportional survival from one to obtain the proportional mortality, and multiplying the proportional mortality by 100 . Empty cells within incubators upon post-treatment collection (i.e., in which embryos had died and decomposed completely) were considered mortalities. Two-way ANOVAs were used to evaluate the effects of treatment type, depth, and the interaction between treatment and depth on embryo mortality for both short-term and long-term sedimentation and ground carcass deposition experiments. The treatment factor had two levels in sedimentation experiments (i.e., control and sediment) and four levels in ground carcass deposition experiments (i.e., control, light, medium, and heavy). The depth factor had two levels (i.e., $0 \mathrm{~cm}$ and $20 \mathrm{~cm}$ ). The response variable was the percent embryo mortality of each incubator. All statistical analyses and model diagnostics were performed and evaluated in R version 3.4.3 (R Foundation for Statistical Computing, Vienna, Austria). Differences were considered significant at $\alpha<0.05$.

[A]Results

[B]Sediment deposition

Sediment deposition at Carrington Island reduced dissolved oxygen concentrations at the substrate surface within treatment plots (Figure 3). Dissolved oxygen concentrations declined by $5.86 \mathrm{mg} / \mathrm{L}$ following sediment deposition on October 
5,2017 , reaching a minimum mean daily dissolved oxygen concentration of $1.38 \mathrm{mg} / \mathrm{L}$ on October 6, 2017. Dissolved oxygen concentrations in treatment plots increased gradually to $8.66 \mathrm{mg} / \mathrm{L}$ on October 25,2017 , and remained similar in control sites from October 25 through December 8 (Figure 3). Dissolved oxygen concentrations within treatment plots began decreasing again from a high of $9.40 \mathrm{mg} / \mathrm{L}$ on December 3, 2017, reaching a minimum mean daily dissolved oxygen concentration of $0.04 \mathrm{mg} / \mathrm{L}$ on February 11, 2018. Dissolved oxygen concentrations varied from 0.05 to $8.71 \mathrm{mg} / \mathrm{L}$ within treatment plots for the remainder of the experiment. Mean daily dissolved oxygen concentrations remained high in control plots for the duration of the experiment, ranging from 8.22 to $11.25 \mathrm{mg} / \mathrm{L}$.

The deposition of sediment did not increase Lake Trout embryo mortality in short-term incubators at Carrington Island treatment plots (Figure 4). Mean percent mortality at the substrate surface was $45 \%(95 \% \mathrm{CI}=31.5-59.3)$ among control embryos and $43 \%(95 \% \mathrm{CI}=29.2-56.6)$ among treatment embryos. Mean percent mortality at 20 cm below the substrate surface was $20 \%(95 \% \mathrm{CI}=8.6-30.6)$ among control embryos and 29\% (95\% CI $=16.7-42.0)$ among treatment embryos. Depth and sediment deposition did not interact to affect embryo mortality (ANOVA: $F_{1,32}=1.54, P=0.22$; Figure 4) and sediment deposition did not affect embryo mortality (ANOVA: $F_{1,32}=$ $0.54, P=0.47$; Figure 4 ); however, depth did affect embryo mortality (ANOVA: $F_{1,32}=$ 15.93, $P<0.001$; Figure 4).

Sediment deposition increased Lake Trout embryo mortality in long-term incubators at Carrington Island (Figure 4). Mean percent mortality at the substrate surface 
was $70 \%(95 \% \mathrm{CI}=57.5-83)$ among control embryos and $97 \%(95 \% \mathrm{CI}=92.9-100)$ among treatment embryos. Mean percent mortality at $20 \mathrm{~cm}$ below the substrate surface was 50\% $(95 \% \mathrm{CI}=35.6-63.5)$ among control embryos and $100 \%$ among treatment embryos. A two-way interaction between treatment and depth (ANOVA: $F_{1,32}=39.10, P$ $<0.001$; Figure 4) indicated that the effect of sediment deposition on embryo mortality was greatest at $20 \mathrm{~cm}$ below the substrate surface.

[B]Ground carcass deposition

Ground carcass deposition at Thomas Bank reduced dissolved oxygen concentrations at the substrate surface in medium and heavy biomass treatment plots, but not in control and light biomass treatment plots (Figure 5). Dissolved oxygen concentrations declined following ground carcass deposition on September 27, 2017, in medium and heavy treatment plots. Mean daily dissolved oxygen concentrations declined from 8.13 to $0.10 \mathrm{mg} / \mathrm{L}$ in medium treatment plots and from 7.90 to $0.06 \mathrm{mg} / \mathrm{L}$ in heavy treatment plots between September 26 and October 5, 2017. Dissolved oxygen concentrations began increasing on October 6, 2017, in medium and heavy treatment plots, reaching 7.75 and $7.10 \mathrm{mg} / \mathrm{L}$, respectively, on October 7, 2017, and remained high for the duration of the experiment (Figure 5).

The application of ground carcass material to experimental plots at Thomas Bank increased short-term Lake Trout embryo mortality (Figure 6). Mean percent mortalities of embryos at the substrate surface were $18 \%(95 \% \mathrm{CI}=7.4-28.6)$ among controls, $64 \%$ $(95 \% \mathrm{CI}=51.1-77.7)$ among light treatment embryos, and 100\% among medium and heavy treatment embryos. Mean percent mortalities at $20 \mathrm{~cm}$ below the substrate surface 
were $12 \%(95 \% \mathrm{CI}=2.5-20.4)$ among controls, $99 \%(95 \% \mathrm{CI}=97.1-100)$ among light treatment embryos, and $100 \%$ among medium and heavy treatment embryos. A two-way interaction between treatment and depth (ANOVA: $F_{3,64}=9.19, P<0.001$; Figure 6) indicated that the effect of increasing ground carcass biomass on embryo mortality was greatest at $20 \mathrm{~cm}$ below the substrate surface.

Long-term effects of ground carcass deposition were similar to short-term effects (Figure 6). Mean percent mortalities of embryos at the substrate surface were $63 \%(95 \%$ $\mathrm{CI}=49.3-76.1)$ among controls, $85 \%(95 \% \mathrm{CI}=75-94.8)$ among light treatment embryos, and $100 \%$ among medium and heavy treatments. Mean percent mortalities at 20 cm below the substrate surface were $29 \%(95 \% \mathrm{CI}=16.3-41.5)$ among controls and $100 \%$ among light, medium, and heavy treatment embryos. A two-way interaction between treatment and depth (ANOVA: $F_{3,64}=35.19, P<0.001$; Figure 6 ) indicated that the effect of increasing ground carcass biomass on embryo mortality was greatest at 20 cm below the substrate surface.

\section{[A]Discussion}

Sediment and ground carcass deposition caused mortality of Lake Trout embryos on Yellowstone Lake spawning sites; however, these suppression methods differed in their effectiveness, rate at which mortality was achieved, and ease of application. Ground carcass deposition was highly effective, caused mortality rapidly, and was relatively easy to apply in the field on the experimental plots. Sediment deposition was effective but labor intensive and caused delayed mortality. Incorporating sediment deposition or ground carcass deposition or both in an Integrated Pest Management approach to Lake 
Trout suppression could provide an additional source of mortality for an oftenunexploited life history stage.

We confirmed that infilling of spawning substrate interstices with sediments containing over $20 \%$ sand $(<2.00 \mathrm{~mm}$ diameter) can be lethal to developing Lake Trout embryos (Hausle and Coble 1976, Sly 1988; Manny et al. 1995; Marsden et al. 1995; Argent and Flebbe 1999; Kock 2004). Sediment deposition was effective at causing high Lake Trout embryo mortality in field experiments at Carrington Island but appeared to take longer than other suppression methods. Deposition of fine sediment can reduce permeability of spawning substrate interstices, thereby causing a reduction in dissolved oxygen delivery to developing embryos (Hausle and Coble 1976; Argent and Flebbe 1999) and reducing survival. All Lake Trout embryos incubated at $10^{\circ} \mathrm{C}$ died at dissolved oxygen concentrations below $3.4 \mathrm{mg} / \mathrm{L}$ in previous laboratory studies (Garside 1959; Carlson and Siefert 1974). Embryos in treatment plots were exposed to mean daily dissolved oxygen concentrations less than $3.4 \mathrm{mg} / \mathrm{L}$ for 92 days between December 2017 and May 2018. Dissolved oxygen concentrations in treatment plots were highly variable compared to control plots during this time. The source of this variability is unclear but may reflect the migration of applied sediment within interstitial spaces. Nonetheless, chronic exposure to low dissolved oxygen concentrations overwinter probably explains the differences between short and long-term embryo mortality observed.

Embryo mortality caused by deposition of ground carcass material in the field corroborated findings of laboratory trials and whole-carcass field applications (Poole 2019; Thomas et al. 2019). Complete embryo mortality was obtained in the heavy 
biomass treatment $\left(28 \mathrm{~kg} / \mathrm{m}^{2}\right)$ at both the substrate surface and $20 \mathrm{~cm}$ within the substrate, as in analogous whole carcass field experiments (Thomas et al. 2019). Complete embryo mortality was also obtained in medium biomass treatments but mortality varied among light treatment plots. The variability derived mostly from a single plot where embryo mortality was markedly lower than in other light treatment plots. Physical attributes of Lake Trout spawning sites such as slope and fetch may influence embryo mortality appreciably at light biomass application plots by maintaining adequate water quality through upwelling or wave action. Nevertheless, a substantial increase in embryo mortality was obtained in light treatment plots relative to controls. A carcass biomass application rate between 7 and $14 \mathrm{~kg} / \mathrm{m}^{2}$ may be required for embryo suppression on Yellowstone Lake spawning sites.

Hypoxia probably caused embryo mortality in ground carcass deposition treatments. Decreasing dissolved oxygen concentrations in the environment reverses the diffusion gradient that supplies developing embryos with oxygen and allows for the accumulation of waste products ultimately causing mortality if conditions persist (Rombough and Randall 1988). Dissolved oxygen requirements of salmonid embryos change as development progresses. Oxygen consumption rises as respiration rate and metabolic activity increase as the embryo grows (Mäenpää et al. 2004). Embryos are most sensitive to hypoxia between 100 and 200 degree days (Alderdice et al. 1958), which occurred between September 29 and October 12, 2017, in our experiments. We observed rapid embryo mortality when dissolved oxygen concentrations declined below $3.4 \mathrm{mg} / \mathrm{L}$ in ground carcass deposition experiments. Dissolved oxygen concentrations fell 
below lethal levels almost immediately (Garside 1959; Carlson and Siefert 1974) after treatment in ground carcass field experiments and remained low for about 9 days in heavy and medium treatment plots, where complete mortality was obtained, as in whole carcass experiments (Thomas et al. 2019). Scattering of ground carcass material by wind and wave action coincided with the subsequent recovery of dissolved oxygen concentrations.

Suction dredging and sediment deposition was difficult and time and labor intensive because clogging of the suction head necessitated frequent stoppages to clear aquatic vegetation. A larger dredge may be more effective and efficient in depositing large amounts of sediment on Lake Trout spawning sites in Yellowstone Lake. Refinement of this technique could be achieved by determining the appropriate dredge for Lake Trout embryo suppression. Sediment deposition may be limited to shallow water spawning sites with suitable fine sediment located in close proximity. Sand and gravel were easiest to direct and apply whereas finer sediments such as silts and clays stayed in suspension and drifted off of treatment plots. Wind and wave action may limit sediment deposition effectiveness at sites exposed to long fetch. Wave-generated turbulence keeps spawning site interstices free of sediment and maintains dissolved oxygen concentrations (Fitzsimons and Marsden 2014). However, recovery of treated sites not exposed to long fetch may be prolonged and sediment deposition could have long-term effects on littoral habitats.

Ground carcass material has advantages and limitations for embryo suppression in Yellowstone Lake. Lake Trout carcass material is available from ongoing gillnetting 
suppression in Yellowstone Lake, and its use in embryo suppression does not involve a net increase in nutrients to the system. However, the use of carcass material would redistribute nutrients sequestered within living Lake Trout to the lower food web. Treatment of the estimated 11.4 ha of Lake Trout spawning habitat in Yellowstone Lake with carcass material is limited by spawning season catch rates (Koel et al. 2020b). Current spawning season catch rates could not support treating 11.4 ha at the recommended 7 to $14 \mathrm{~kg} / \mathrm{m}^{2}$ rate for successful embryo suppression. Moreover, carcass deposition may be limited to protected shallow water sites where prescribed concentrations of carcass material can be achieved. Carcass material can attract wildlife (Thomas et al. 2019), and therefore its use may be limited to remote spawning sites where human-wildlife conflicts are improbable. Ground carcass deposition may affect littoral communities in Yellowstone Lake. Although no short-term increase in substrate biofilm has been detected following carcass deposition experiments (Thomas 2017), large-scale application of these methods may influence littoral community structure. Avoiding over-application of ground carcass material (i.e., $>14 \mathrm{~kg} / \mathrm{m}^{2}$ ) is suggested to alleviate this concern. However, monitoring the biotic community of Lake Trout spawning sites treated with carcass material will be required to understand any potential negative effects this method may have if applied at larger spatial scales.

Large-scale treatment of spawning sites with ground carcass material or sediment will be required to reduce Lake Trout embryo survival in Yellowstone Lake. Prepositioned sentinel incubators or dissolved oxygen concentration data loggers or both could be used to evaluate the efficacy of large-scale treatments. Maintenance of dissolved 
oxygen concentrations below $3.4 \mathrm{mg} / \mathrm{L}$ for $200 \mathrm{~h}$ can be considered a reliable predictor of embryo mortality (Koel et al. 2020b). These techniques could be used alongside emergent fry trapping to evaluate success of embryo suppression activities at treated spawning sites (Marsden et al. 1988).

Implementation of effective embryo suppression methods would complement traditional gillnetting techniques in an Integrated Pest Management approach and hasten Lake Trout population decline (Sawyer 1980; Christie and Goddard 2003; Lechelt and Bajer 2016; Brown 2017; Thomas et al. 2019). Embryo suppression may be particularly important in Yellowstone Lake, where Lake Trout embryo feeding and growth are greater (Simard et al. 2020) and pre-recruit survival is 4 to 6 times higher than among Lake Trout populations within their native range (Syslo et al. 2020). Furthermore, Lake Trout population growth rates are highly sensitive to age-0 survival rates (Ferreri et al. 1995; Syslo et al. 2011; Cox et al. 2013), and therefore successful embryo suppression could have population-level effects. Embryo suppression may also become increasingly costeffective as adult Lake Trout density decreases in Yellowstone Lake and cost per Lake Trout harvested by traditional methods increases. Moreover, development, evaluation, and refinement of novel suppression techniques would be beneficial, especially of techniques or compounds that could reduce dissolved oxygen concentrations within spawning substrates but that do not require nutrient additions, such as (potentially) sodium sulfite and related salts (Westman and Hunter 1956; Dawson and Kolar 2003). [A]Acknowledgments 
We thank Carter Fredenberg for his insightful review of an early version of this manuscript. Funding for this study was provided by Yellowstone Forever Grant G-022 and the U.S. National Park Service, Yellowstone National Park. The Montana Cooperative Fishery Research Unit is jointly sponsored by the U.S. Geological Survey, Montana Fish, Wildlife \& Parks, Montana State University, and the U.S. Fish and Wildlife Service. Any use of trade, firm, or product names is for descriptive purposes only and does not imply endorsement by the U.S. Government. This study was performed under the auspices of Montana State University institutional animal care and use protocols 2014-40, 2015-28, and 2016-42.

\section{[A]References}

Alderdice, D. F., W. P. Wickett, and J. R. Brett. 1958. Some effects of temporary exposure to low dissolved oxygen levels on Pacific salmon eggs. Journal of the Fisheries Research Board of Canada 15:229-250.

Argent, D. G., and P. A. Flebbe. 1999. Fine sediment effects on Brook Trout eggs in laboratory streams. Fisheries Research 39:253-262.

Benson, N. G. 1961. Limnology of Yellowstone Lake in relation to the Cutthroat Trout. U.S. Fish and Wildlife Service, Research Report 56.

Brown, P. J., C. S. Guy, and M. H. Meeuwig. 2017. A comparison of two mobile electrode arrays for increasing mortality of Lake Trout embryos. North American Journal of Fisheries Management 37:363-369.

Callaghan, D. T., P. J. Blanchfield, and P. A. Cott. 2016. Lake Trout (Salvelinus namaycush) spawning habitat in a northern lake: the role of wind and physical characteristics on habitat quality. Journal of Great Lakes Research 42:299-307.

Carlson, A. R., and R. E. Siefert. 1974. Effects of reduced oxygen on the embryos and larvae of Lake Trout (Salvelinus namaycush) and Largemouth Bass (Micropterus salmoides). Journal of the Fisheries Research Board of Canada 31:1393-1396.

Christie, G. C., and C. I. Goddard. 2003. Sea Lamprey International Symposium (SLIS II): advances in the integrated management of Sea Lamprey in the Great Lakes. Journal of Great Lakes Research 29:1-14. 
Cox, B. S. 2010. Assessment of an invasive Lake Trout population in Swan Lake, Montana. Master's thesis. Montana State University, Bozeman.

Cox, B. S., C. S. Guy, W. A. Fredenberg, and L. R. Rosenthal. 2013. Baseline demographics of a non-native Lake Trout population and inferences for suppression from sensitivity-elasticity analyses. Fisheries Management and Ecology 20:390-400.

Dawson, V. K., and C. S. Kolar. 2003. Integrated management techniques to control nonnative fishes. Completion Report submitted to the Bureau of Reclamation by the U.S. Geological Survey, Upper Midwest Environmental Sciences Center, La Crosse, Wisconsin.

Ferreri, C. P., W. W. Taylor, and D. B. Hayes. 1995. Evaluation of age-0 survival and its effects on Lake Trout rehabilitation in the Michigan waters of Lake Superior. Journal of Great Lakes Research 21:218-224.

Finn, R. N. 2007. The physiology and toxicology of salmonid eggs and larvae in relation to water quality criteria. Aquatic Toxicology 81:337-354.

Fitzsimons, J. D., and J. E. Marsden. 2014. Relationship between Lake Trout spawning, embryonic survival, and currents: a case of bet hedging in the face of environmental stochasticity? Journal of Great Lakes Research 40:92-101.

Fredenberg, C. R., C. C. Muhlfeld, C. S. Guy, V. S. D’Angelo, C. C. Downs, and J. M. Syslo. 2017. Suppression of invasive Lake Trout in an isolated backcountry lake in Glacier National Park. Fisheries Management and Ecology 24:33-48.

Garside, E. T. 1959. Some effects of oxygen in relation to temperature on the development of Lake Trout embryos. Canadian Journal of Zoology 37:689-698.

Gresswell, R. E. 2011. Biology, status, and management of the Yellowstone Cutthroat Trout. North American Journal of Fisheries Management. 31:782-812.

Gresswell, R. E., and W. J. Liss. 1995. Values associated with management of Yellowstone Cutthroat Trout in Yellowstone National Park. Conservation Biology 9:159-165.

Gunn, J. M. 1995. Spawning behavior of Lake Trout: effects on colonization ability. Journal of Great Lakes Research 21:323-329.

Gunn, J. M., and W. Keller. 1984. Spawning site water chemistry and Lake Trout (Salvelinus namaycush) sac fry survival during spring snowmelt. Canadian Journal of Fisheries and Aquatic Sciences 41:319-329. 
Haines, T. A., and J. P. Baker. 1986. Evidence of fish population responses to acidification in the eastern United States. Water, Air, \& Soil Pollution 31:605629.

Hausle, D. A., and D. W. Coble. 1976. Influence of sand in redds on survival and emergence of Brook Trout (Salvelinus fontinalis). Transactions of the American Fisheries Society 105:57-63.

Johnson, B. M., R. Arlinghaus, and P. J. Martinez. 2009. Are we doing all we can to stem the tide of illegal fish stocking? Fisheries 34:389-394.

Kaeding, L. R., G. D. Boltz, and D. G. Carty. 1996. Lake Trout discovered in Yellowstone Lake threaten native Cutthroat Trout. Fisheries 21(3):16-20.

Kaplinski, M. 1991. Geomorphology and geology of Yellowstone Lake, Yellowstone National Park, Wyoming. Master's thesis, Northern Arizona University, Flagstaff.

Kock, T. J. 2004. Effects of sedimentation and water velocity on White Sturgeon (Acipenser transmontanus) embryo survival. Master's thesis. University of Idaho, Moscow.

Koel, T. M., J. L. Arnold, P. E. Bigelow, T. O. Brenden, J. D. Davis, C. R. Detjens, P. D. Doepke, B. D. Ertel, H. C. Glassic, R. E. Gresswell, C. S. Guy, D. J. MacDonald, M. E. Ruhl, T. J. Stuth, D. P. Sweet, J. M. Syslo, N. A. Thomas, L. M. Tronstad, P. J. White, and A. V. Zale. 2020a. Yellowstone Lake ecosystem restoration: A case study for invasive fish management. Fishes 5:18.

Koel, T. M., J. L. Arnold, P. E. Bigelow, and M. E. Ruhl. 2010. Native Fish Conservation Plan. Environmental Assessment, December 16, 2010. National Park Service, U.S. Department of the Interior, Yellowstone National Park, Wyoming.

Koel, T. M., P. E. Bigelow, P. D. Doepke, B. D. Ertel, and D. L. Mahony. 2005. Nonnative Lake Trout result in Yellowstone Cutthroat Trout decline and impacts to bears and anglers. Fisheries 30:10-19.

Koel, T. M., N. A. Thomas, C. S. Guy, P. D. Doepke, D. J. MacDonald, A. S. Poole, W. M. Sealey, and A. V. Zale. 2020b. Organic pellet decomposition induces mortality of Lake Trout embryos in Yellowstone Lake. Transactions of the American Fisheries Society 149:57-70.

Koel, T. M., L. M. Tronstad, J. L. Aronld, K. A. Gunther, D. W. Smith, J. M. Syslo, and P. J. White. 2019. Predatory fish invasion induces within and across ecosystem effects in Yellowstone National Park. Science Advances 5:eaav1139. 
Lechelt, J. D., and P. G. Bajer. 2016. Modeling the potential for managing invasive Common Carp in temperate lakes by targeting their winter aggregations. Biological Invasions 18:831-839.

Mäenpää, K. A., O.-P. Penttinen, and J. V. Kukkonen. 2004. Pentachlorophenol (PCP) bioaccumulation and effect on heat production on salmon eggs at different stages of development. Aquatic Toxicology 68:75-85.

Manny, B. A., T. A. Edsall, J. W. Peck, G. W. Kennedy, and A. M. Frank. 1995. Survival of Lake Trout eggs on reputed spawning grounds in Lakes Huron and Superior: in situ incubation, 1987-1988. Journal of Great Lakes Research 21:302-312.

Marsden, J. E., J. M. Casselman, T. A. Edsall, R. F. Elliott, J. D. Fitzsimons, W. H. Horns, B. A. Manny, S. C. McAughey, P. G. Sly, and B. L. Swanson. 1995. Lake Trout spawning habitat in the Great Lakes - a review of current knowledge. Journal of Great Lakes Research 21:487-497.

Marsden, J. E., C. C. Krueger, and C. P. Schneider. 1988. Evidence of natural reproduction by stocked Lake Trout in Lake Ontario. Journal of Great Lakes Research 14:3-8.

Martinez, P. J., P. E. Bigelow, M. A. Deleray, W. A. Fredenberg, B. S. Hansen, N. J. Horner, S. K. Lehr, R. W. Schneidervin, S. A. Tolentino, and A. E. Viola. 2009. Western Lake Trout woes. Fisheries 34:424-442.

McMahon, T. E., and D. H. Bennett. 1996. Walleye and Northern Pike: boost or bane to northwest fisheries? Fisheries 21(8):6-13.

Ng, E. L., J. P. Fredericks, and M. C. Quist. 2016. Population dynamics and evaluation of alternative management strategies for nonnative Lake Trout in Priest Lake, Idaho. North American Journal of Fisheries Management 36:40-54.

Pimentel, D., R. Zuniga, and D. Morrison. 2005. Update on the environmental and economic costs associated with alien-invasive species in the United States. Ecological Economics 52:273-288.

Poole, A. S. 2019. Evaluation of suppression methods for nonnative Lake Trout in Yellowstone Lake, Yellowstone National Park, Wyoming, USA. Master's thesis. Montana State University, Bozeman.

Rombough, P. J., and D. J. Randall. 1988. Respiratory gas exchange, aerobic metabolism, and effects of hypoxia during early life. Pages 59-161 in W. S. Hoar, editor. Fish Physiology, Academic Press, New York. 
Ruzycki, J. R., D. A. Beauchamp, and D. L. Yule. 2003. Effects of introduced Lake Trout on native Cutthroat Trout in Yellowstone Lake. Ecological Applications 13:2337.

Sawyer, A. J. 1980. Prospects for integrated pest management of the Sea Lamprey (Petromyzon marinus). Canadian Journal of Fisheries and Aquatic Sciences 37:2081-2092.

Simard, L. G., J. E. Marsden, R. E. Gresswell, and M. Euclide, 2020. Rapid early development and feeding benefits an invasive population of Lake Trout. Canadian Journal of Fisheries and Aquatic Sciences 77:496-504, doi:10.1139/cjfas-20190122.

Simberloff, D. 2014. Biological invasions: What's worth fighting and what can be won? Ecological Engineering 65:112-121.

Sly, P. G. 1988. Interstitial water quality of Lake Trout spawning habitat. Journal of Great Lakes Research 14:301-315.

Syslo, J. M., T. O. Brenden, C. S. Guy, T. M. Koel, P. E. Bigelow, P. D. Doepke, J. L. Arnold, and B. D. Ertel. 2020. Could ecological release buffer suppression efforts for non-native Lake Trout (Salvelinus namaycush) in Yellowstone Lake, Yellowstone National Park? Canadian Journal of Fisheries and Aquatic Sciences 77:1010-1025, doi:10.1139/cjfas-2019-0306.

Syslo, J. M., C. S. Guy, P. E. Bigelow, P. D. Doepke, B. D. Ertel, and T. M. Koel. 2011. Response of non-native Lake Trout (Salvelinus namaycush) to 15 years of harvest in Yellowstone Lake, Yellowstone National Park. Canadian Journal of Fisheries and Aquatic Sciences 68:2132-2145.

Syslo, J. M., C. S. Guy, and T. M. Koel. 2016. Feeding ecology of native and nonnative salmonids during the expansion of a nonnative apex predator in Yellowstone Lake, Yellowstone National Park. Transactions of the American Fisheries Society 145:476-492.

Thomas, N. A. 2017. Evaluation of suppression methods targeting non-native Lake Trout in Yellowstone Lake, Yellowstone National Park, Wyoming, USA. Master's thesis. Montana State University, Bozeman.

Thomas, N. A., C. S. Guy, T. M. Koel, and A. V. Zale. 2019. In-situ evaluation of benthic suffocation methods for suppression of invasive Lake Trout embryos in Yellowstone Lake. North American Journal of Fisheries Management. 39:104111.

Varley, J. D., and P. Schullery. 1995. Socioeconomic values associated with the Yellowstone Lake Cutthroat Trout. Pages 22-27 in J. D. Varley and P. Schullery, 
editors. The Yellowstone Lake crisis: confronting a Lake Trout invasion. Report to the Director of the National Park Service. Yellowstone Center for Resources, Yellowstone National Park, Wyoming.

Varley, J. D., and P. Schullery. 1998. Yellowstone fishes: ecology, history and angling in the park. Stackpole Books, Mechanicsburg, PA.

Wagner, W. C. 1982. Lake Trout spawning habitat in the Great Lakes. Fisheries research report 1904. Michigan Department of Natural Resources, Fisheries Division, Lansing.

Westman, J. R., and J. V. Hunter. 1956. Preliminary observations on the lowering of dissolved oxygen by sodium sulfite and its effects on certain fishes, with particular reference to problems in fish management. The Progressive FishCulturist 18:126-130. 


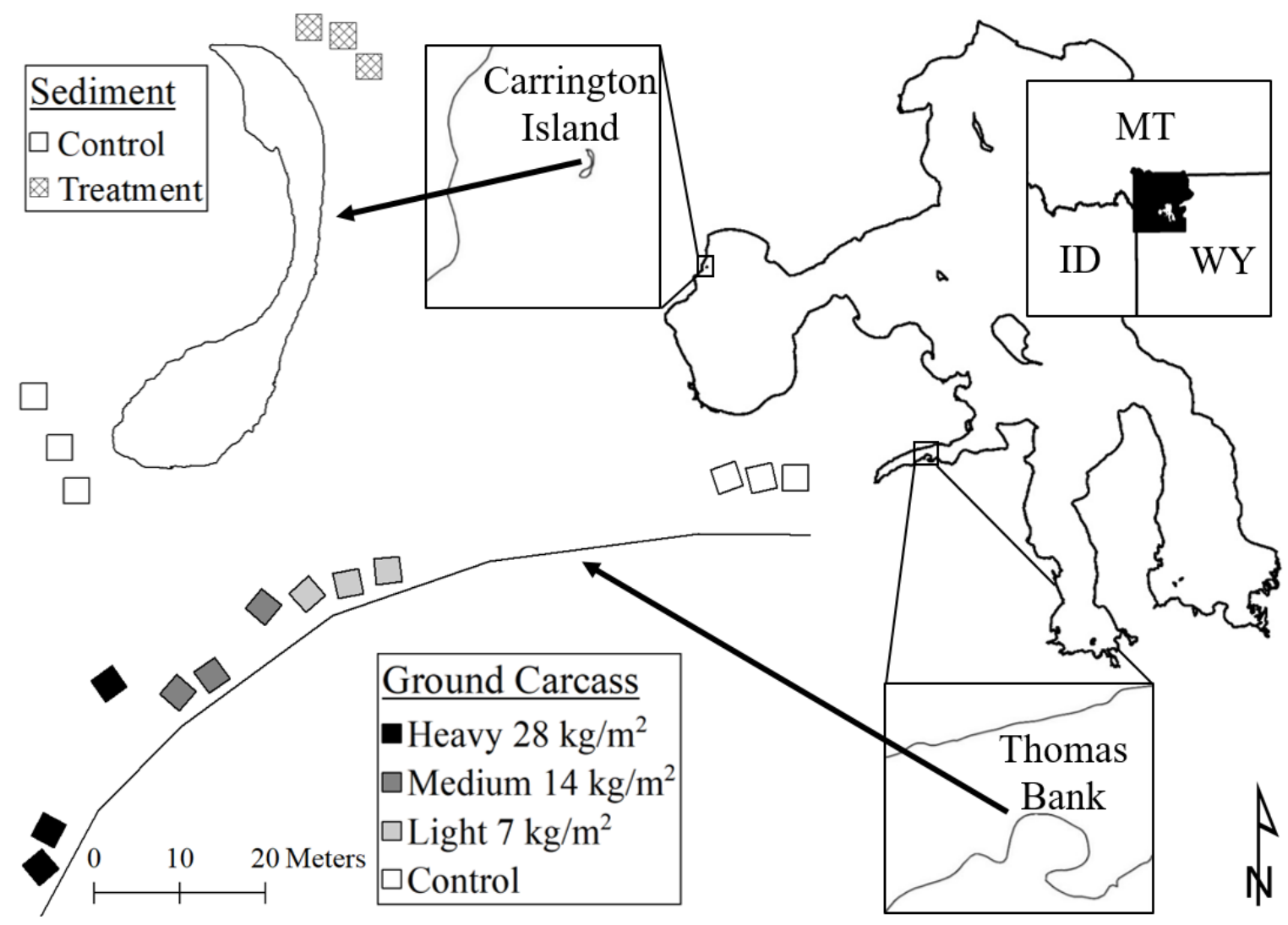

FIGURE 1. Map of Yellowstone Lake within Yellowstone National Park (the black area in the inset panel) and locations of Lake Trout spawning sites where in-situ Lake Trout embryo suppression experiments were conducted. Ground carcass experiments were conducted at Thomas Bank in the Flat Mountain Arm (44.372087,$\left.-110.419515^{\circ}\right)$. Sedimentation experiments were conducted at Carrington Island in the West Thumb $\left(44.456584^{\circ},-110.554971^{\circ}\right)$. 

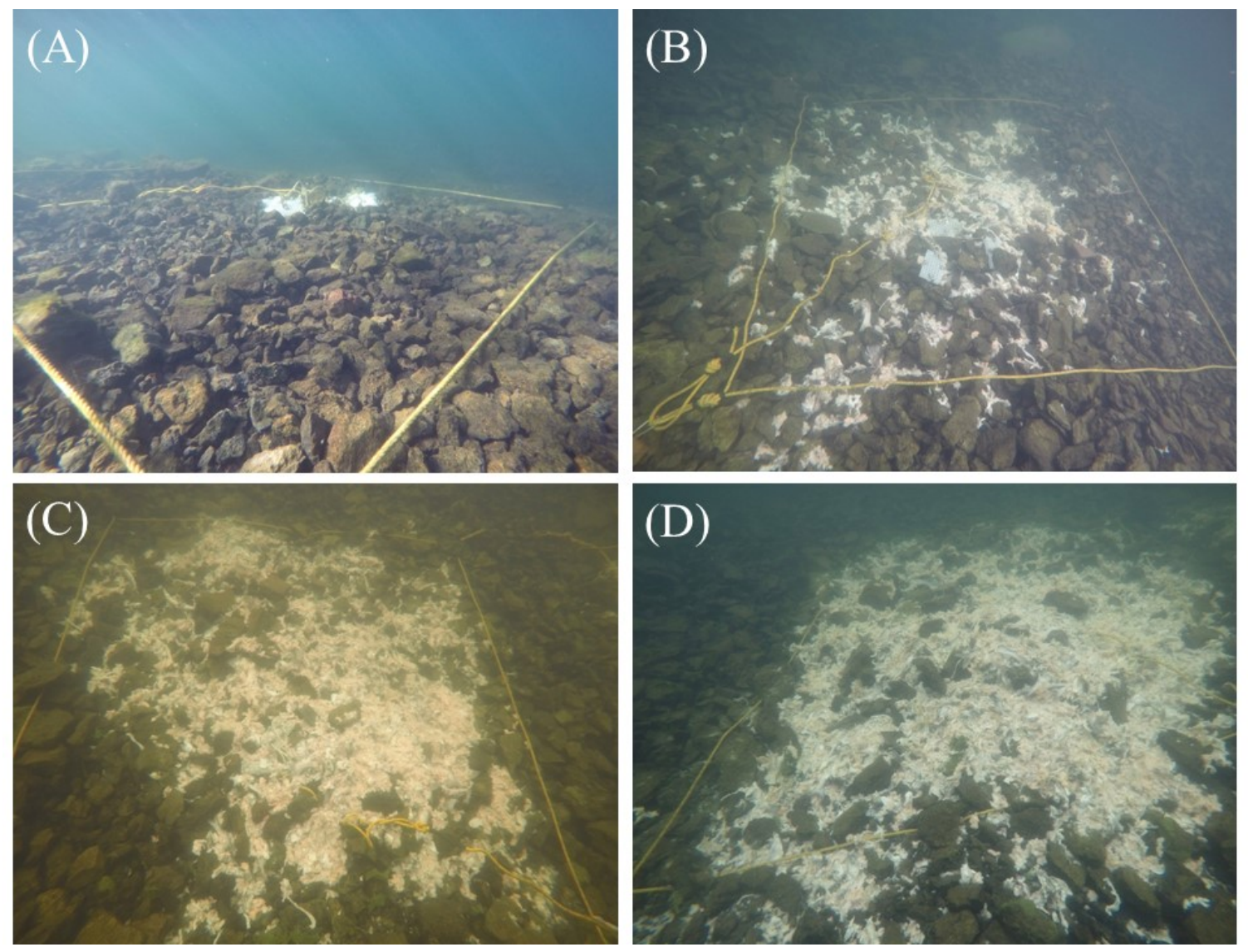

FIGURE 2. Examples of $9-\mathrm{m}^{2}$ plots used as (A) controls, and treatments including (B) light treatment plots treated with $7 \mathrm{~kg} / \mathrm{m}^{2}$ of ground carcasses, $(C)$ medium treatment plots treated with $14 \mathrm{~kg} / \mathrm{m}^{2}$ of ground carcasses, and (D) heavy treatment plots treated with $28 \mathrm{~kg} / \mathrm{m}^{2}$ of ground carcasses. Plots were delineated by yellow polypropylene rope. Embryo incubators and water quality logger are visible at the surface of the control plot. 


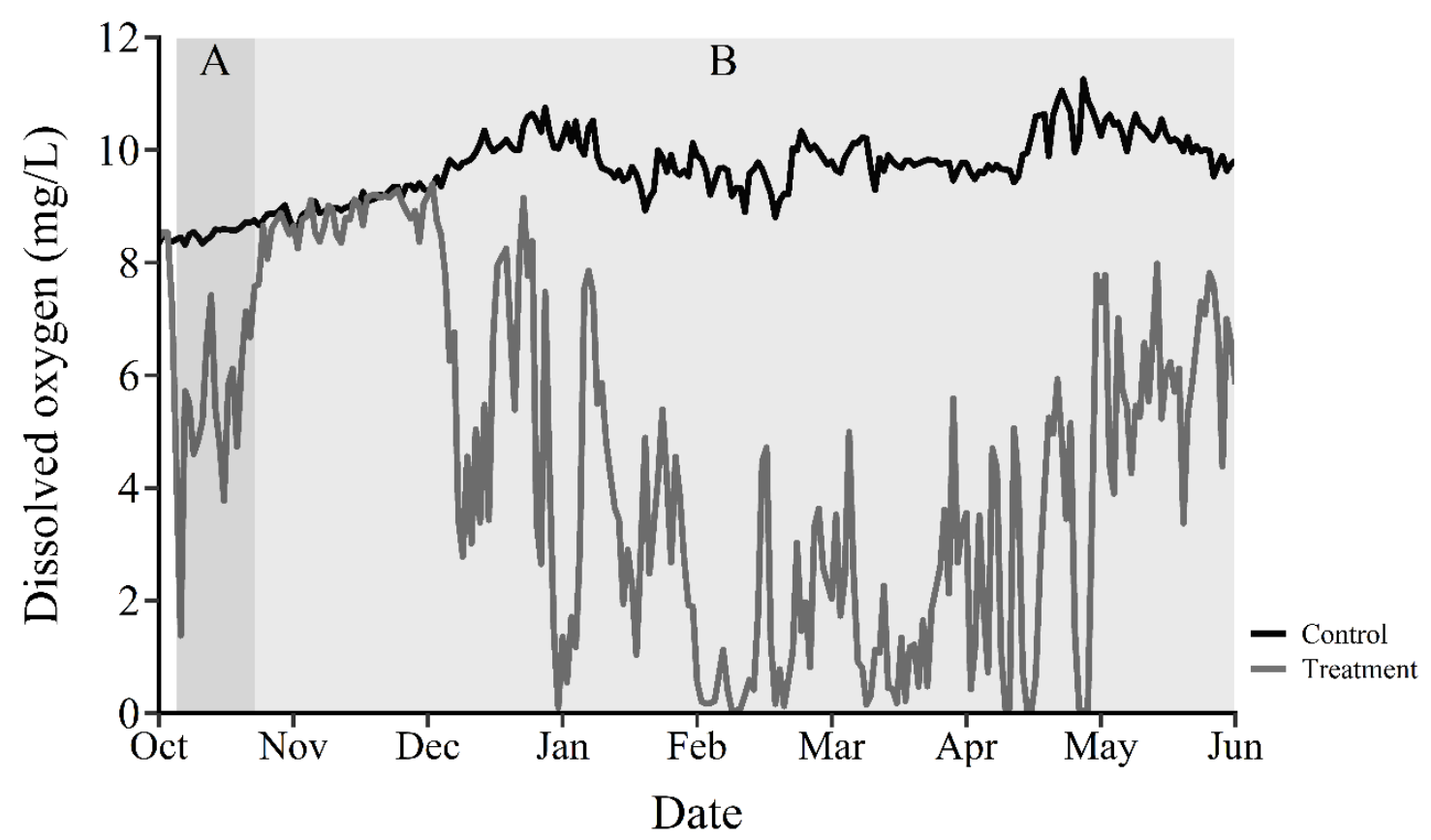

FIGURE 3. Mean daily dissolved oxygen concentrations (mg/L) during short-term (18 days; dark gray labeled A) and long-term (249 days; light gray labeled B) sediment deposition experiments at the substrate surface within control plots (black line) and treatment plots (gray line) at Carrington Island, Yellowstone Lake. Sediment was deposited at treatment plots on October 5, 2017. Long-term incubators were recovered on June 12, 2018. 


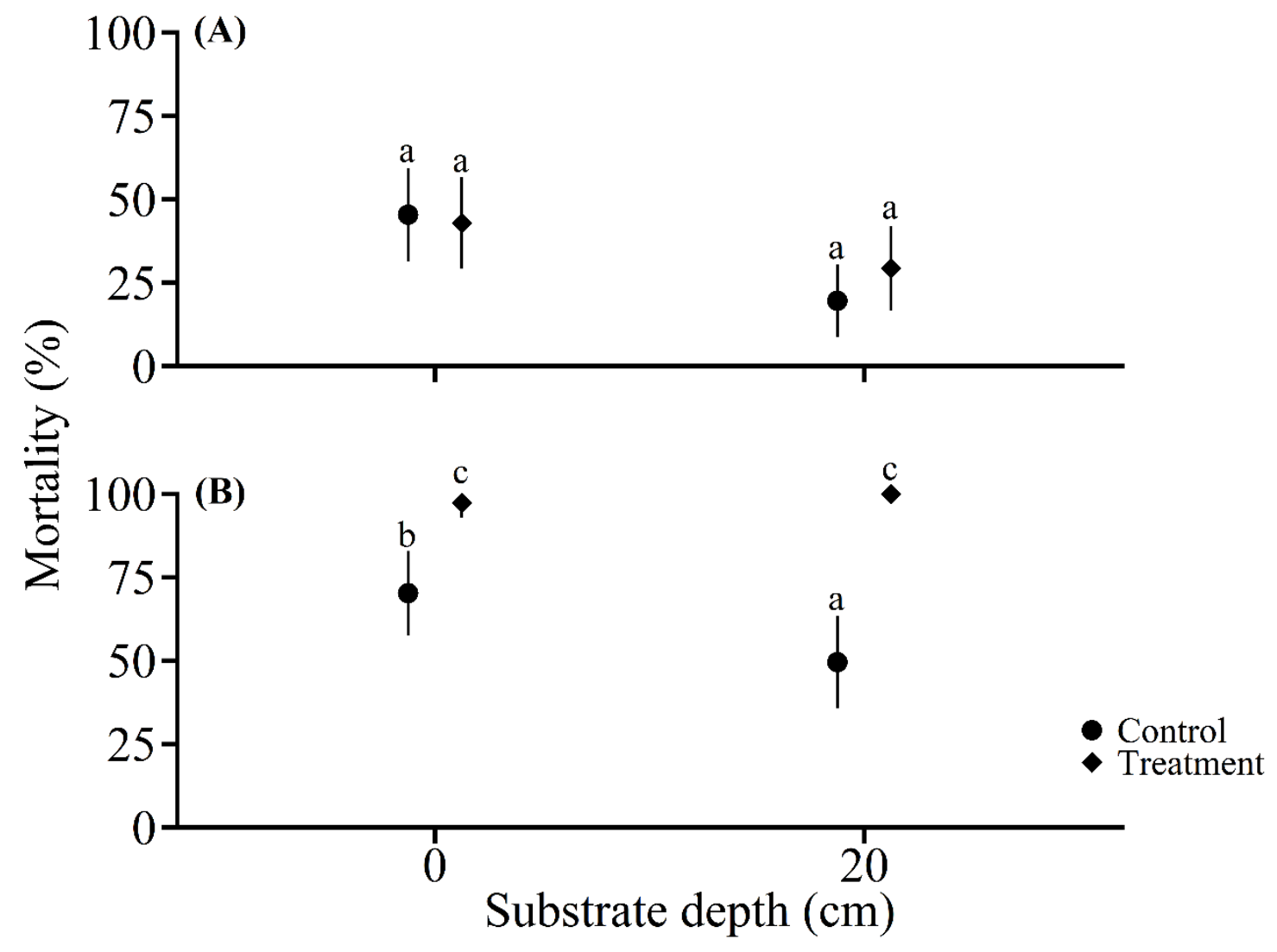




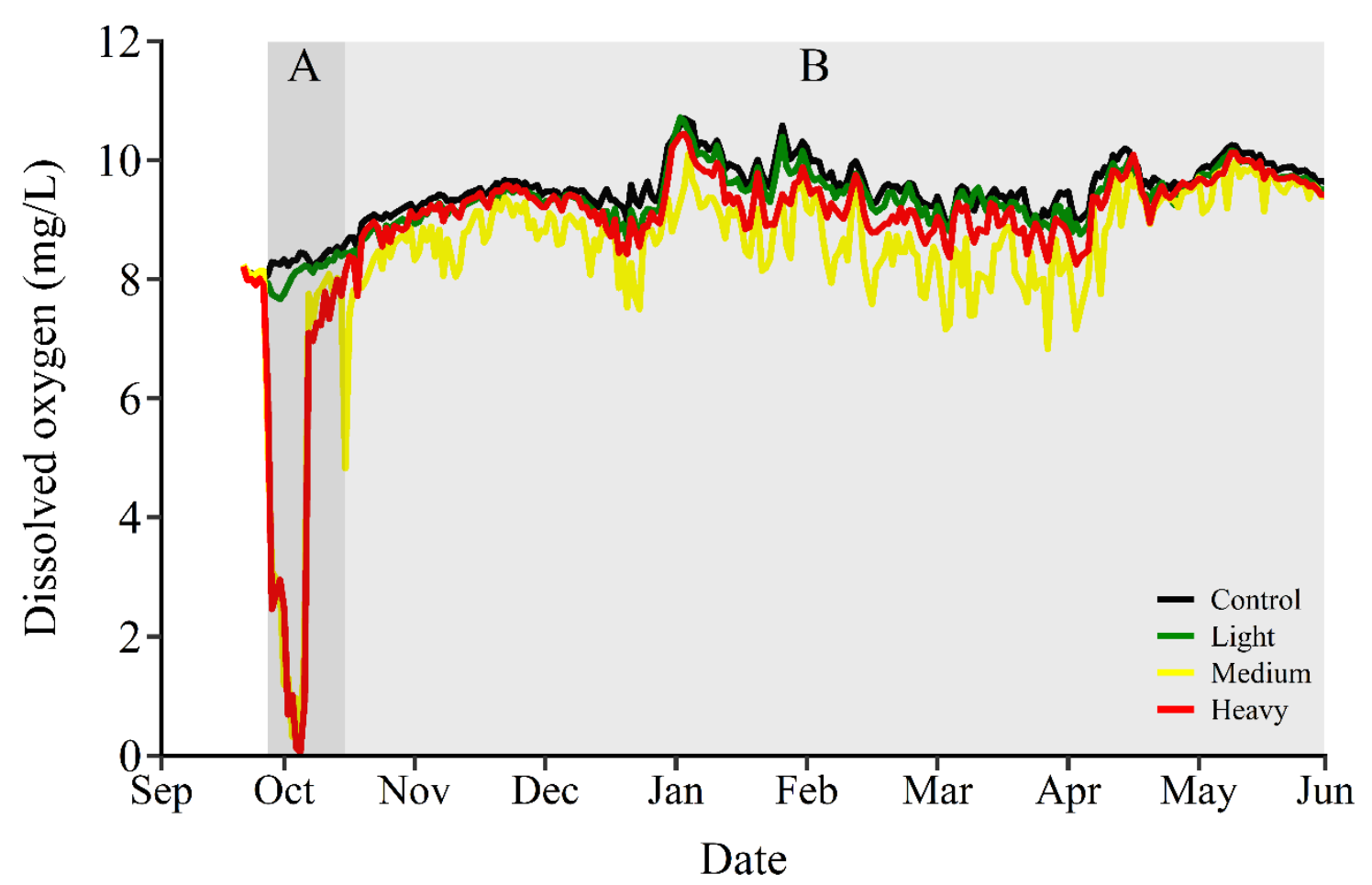

FIGURE 5. Mean daily dissolved oxygen concentrations (mg/L) during short term (19 days; dark gray labeled A) and long-term (256 days; light gray labeled B) experiments at the substrate surface within control plots (solid line), light treatment plots treated with 7 $\mathrm{kg} / \mathrm{m}^{2}$ of ground Lake Trout carcasses, medium treatment plots $\left(14 \mathrm{~kg} / \mathrm{m}^{2}\right)$, and heavy treatment plots $\left(28 \mathrm{~kg} / \mathrm{m}^{2}\right)$. Ground carcasses were placed on the substrate at treatment plots on September 27, 2017. Long-term incubators were recovered on June 14, 2018. 


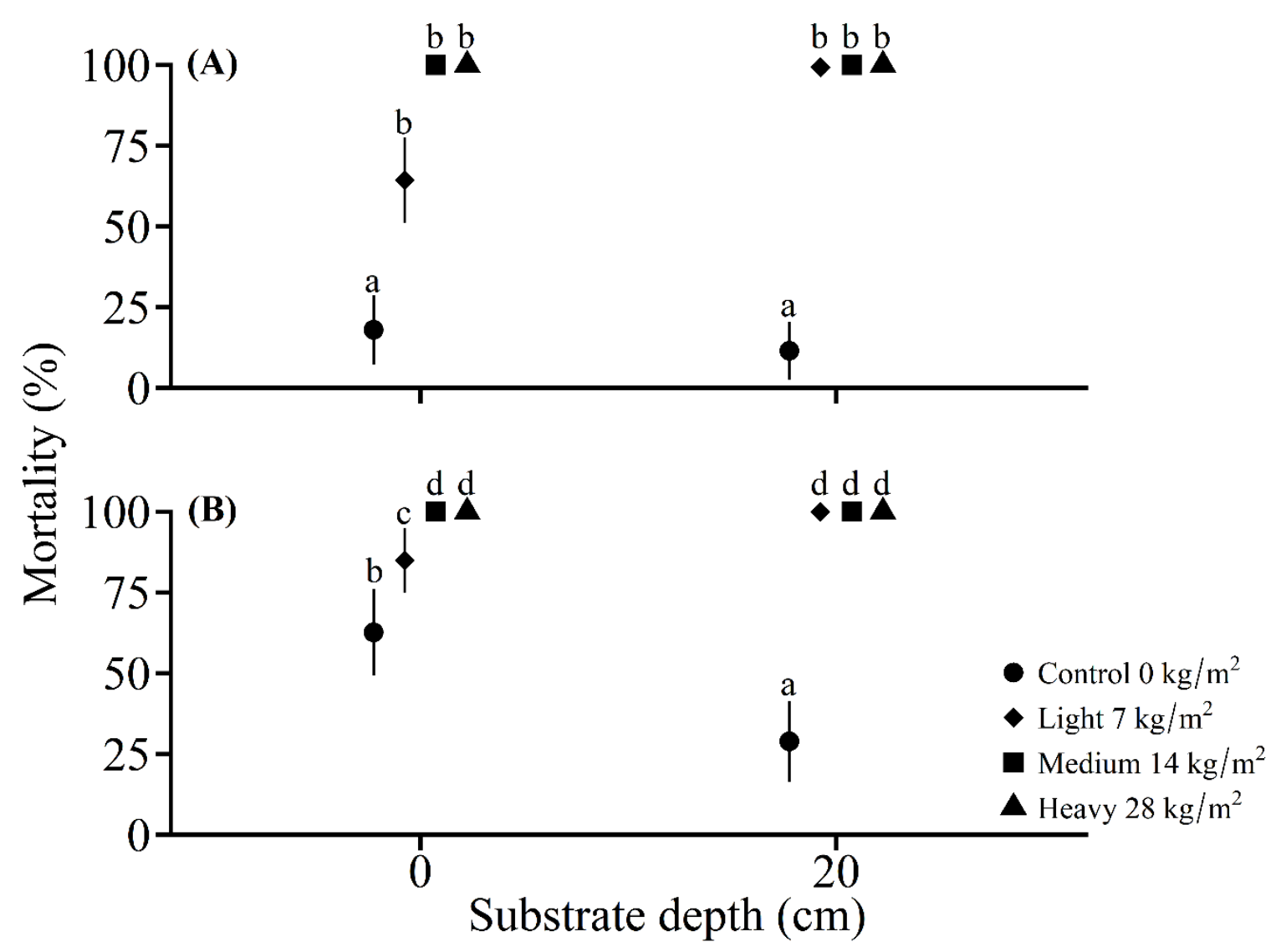

FIGURE 6. Percent mortality of Lake Trout embryos (mean $\pm 95 \%$ CL) in (A) short-term and (B) long-term ground carcass deposition experiments at Thomas Bank, Yellowstone Lake. Incubators were placed at the substrate surface $(0 \mathrm{~cm})$ and $20 \mathrm{~cm}$ below the substrate surface in control plots (circles, $n=3$ ), light treatment plots (diamonds, $n=3$ ) treated with $7 \mathrm{~kg} / \mathrm{m}^{2}$ of ground carcasses, medium treatment plots (squares, $n=3$ ) treated with $14 \mathrm{~kg} / \mathrm{m}^{2}$ of ground carcasses, or heavy treatment plots (triangles, $n=3$ ) treated with $28 \mathrm{~kg} / \mathrm{m}^{2}$ of ground carcasses. Short-term experiments were conducted in autumn 2017 for 19 days and long-term experiments were conducted from September 2017 through June 2018 for 256 days. Means denoted by the same letters (a-d) were not significantly different. 